\title{
短時間負荷条件下の円筒物体把握における最大保持力径についで
}

\author{
加茂 美 冬*1, 森 本茂*2 \\ 八 高 隆 雄*3, 山本 圭治郎*4
}

\section{Diameter of Cylinder with Maximum Holding Force under Rapid Loading Conditions}

\author{
Mifuyu KAMO, Shigeru MORIMOTO, \\ Takao YAKOU and Keijiro YAMAMOTO
}

\begin{abstract}
The aim of this study is to investigate the relation between diameter of cylindrical object and holding force under the condition of rapid increment of load. The holding force was in a range from 100 to $300 \mathrm{~N}$ at the diameter of cylinder between 15 and $60 \mathrm{~mm}$. The maximum force was obtained from the cylinder with a diameter of 20 and $25 \mathrm{~mm}$. In the comparison with the results from the static holding condition, the present results showed that the larger force was appeared at the thinner cylinder. When electromyogram was recorded from the grasping muscles during constant loading, the integrated value of the electromyogram showed the minimum value at the cylinder diameter at which the maximum force was obtained. Experimental results show the existence of the optimum diameter to transmit the muscle force to the cylindrical object with good efficiency.
\end{abstract}

Key Words: Human Engineering, Human Interface, Measurement, Grasping of Cylindrical Object, Rapid Loading Condition, Holding Force, Sensory Evaluation, Electromyogram, Hand Dimension, Contact Area between Hand and Object

\section{1. 緒言}

物体を把握する場合の物体と手の間には最も力を伝

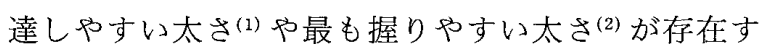
ることが明らかになってきた。これらの研究は，機械 のハンドルや道具の柄の太さの設計を目的としている ものであり, 手と物体の間では負荷速度は急に変わら ない，いわゆる静的な力伝達を対象としている．しか し，使用する道具によっては短時間に負荷が変化する ものも少なくない. 夕ガネやハンマなどの生産工具の みならず，野球のバットやテニスラケットなどでも短 時間における力の伝達が重要である.

本報では, 5 秒以内の短い時間内に最大値に達する ような短時間負荷の下における物体と手の間の力の伝 達について従来の把握 (600 秒以上の時間を要する把 握，以下静的把握とする)と比較するとともに，筋電図 を介して把握時の筋活動について検討を行った.

* 原稿受付 1997 年 9 月 17 日.

*1 正員, 横浜国立大学教育人間科学部(业 240-0067 横浜市保土 分谷区常盤 79-2).

*2 横浜国立大学教育人間科学部.

*3 正員, 横浜国立大学工学部 (画 240-0067 横浜市保土ヶ谷区常 盤台 79-5)

*4 正員, 神奈川工科大学工学部(亚 243-0292 厚木市下荻野 1030).

\section{2. 実 験 方 法}

被験者は, 神経筋疾患をもたない健康な 24〜 45 歳 の成人 5 名とし, 右手(優位側)を被験手とした。被験 者にはあらかじめ研究の目的, 方法について説明し, 実験に参加することに対する同意を得た。図 1 に手の 模式図を示す。また, 図 1 に示した各部位の各被験者 の手の大きさは表 1 のと扔りであった。すべての実験 を行ったのは表 1 中の*印で示した 5 名中 2 名の被験 者であった。

把握実験の方法は前報(1) 同様とし，被験者は図 2 に 示す状態で円筒を垂直に把握保持した。円筒物体は, アクリル製で長さ $30 \mathrm{~cm}$, 直径 $5 \sim 60 \mathrm{~mm}$ の範囲で 5 $\mathrm{mm}$ 間隔のものを用いた. 被験者には, 把握中, 前腕 の回転や手関節の背屈や尺屈等が起こらないように指 示した. 把握時の保持力は, 円筒を把握した状態で垂 直下方に負荷を加え, 負荷に耐えられなくなった時点 での負荷量で定義した。短時間負荷は牽引することに よって与え, 把握力はほぼ 1 秒以内で最大值の $90 \%$ 以 内の範囲に達し，その後 5 秒以内に耐えられなくなっ た.また，静的負荷は前報(1)同様に円筒にバケツを下 げ，その中へ水を注ぐことにより行った。

表面筋電図は，図3に示すように骨間筋(volar 
Table 1 Dimensions of subject's hand

\begin{tabular}{|c|c|c|c|c|}
\hline Subj. & L1 & L2 & L5 & L10 \\
\hline MK & 167 & 95 & 72 & 73 \\
\hline SM & 181 & 102 & 79 & 90 \\
\hline SA & 172 & 96 & 76 & 74 \\
\hline SYU & 188 & 107 & 81 & 85 \\
\hline YN & 188 & 108 & 80 & 90 \\
\hline
\end{tabular}

L1: hand length, L2: palm length

L5: middle finger length, L10: hand breadth

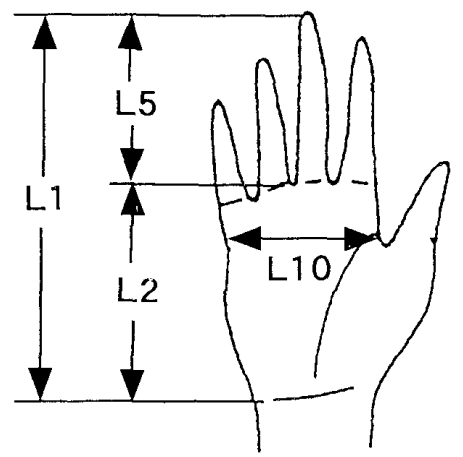

Fig. 1 Hand dimensions determined

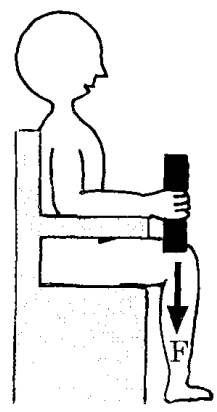

Fig. 2 Experimental set up

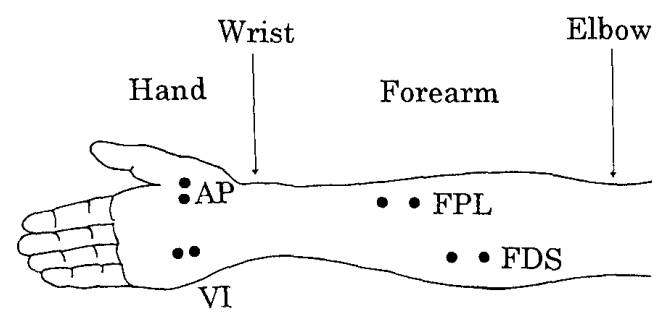

Fig. 3 Schematic illustration of EMG recording positions in hand and forearm $\left[\begin{array}{l}\text { AP : adductor pollicis } \\ \text { VI : volar interossei } \\ \text { FPL : flexor pollicis longus } \\ \text { FDS : flexor digitorum sublimis }\end{array}\right]$

interossei：VI), 母指内転筋 (adductor pollicis： AP) と浅指屈筋(flexor digitorum sublimis: FDS), 長母指屈筋, (flexor pollicis longus：FPL) から記録 した，筋電位は，直径 $5 \mathrm{~mm}$ の $\mathrm{Ag} / \mathrm{AgCl}$ 血電極を用
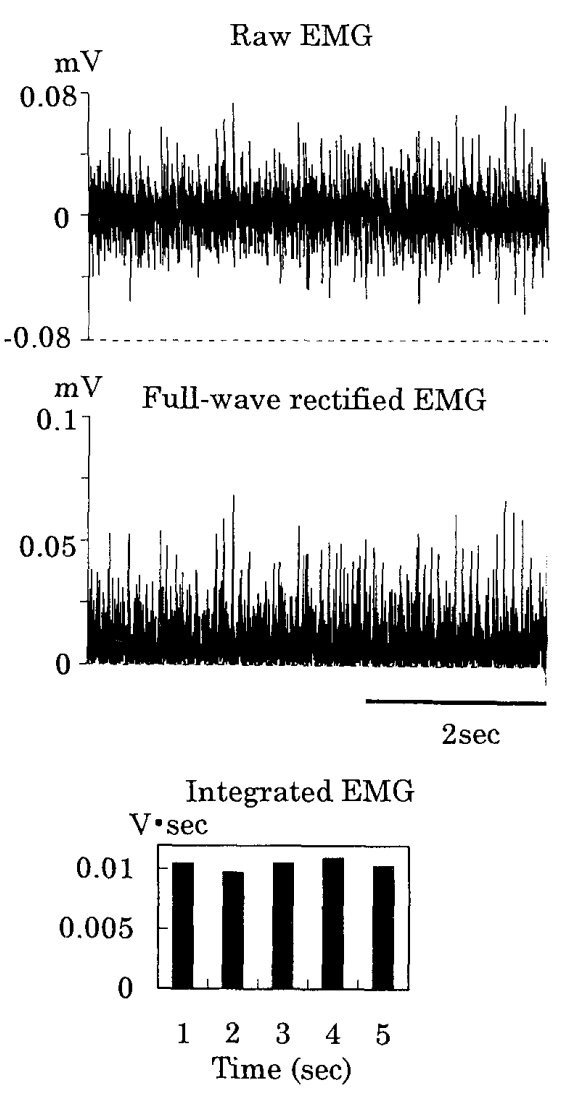

Fig. 4 Process of EMG analysis

いた双極誘導法によって求めた。このときの電極間距 離は 15 20 mm であった。導出電位は, 周波数帯域 3〜10 kHz にて差動増幅(ダイアメディカルシステム, DPA 400 C) ᄂ, FM カセットレコーダ(TEAC, R31)に記録した。その後，A/D コンバー夕を通してパ ーソナルコンピュータに入力し, 積分值を算出した (BIMUTAS，キッセイ)。算出手順は，図 4 に示すよ うに, 把握開始 3 秒後からの 5 秒間の筋電図 (Raw EMG)を全波整流 (Full-wave rectified EMG) した後, 1 秒ごとに積分值を算出した。 それらを平均した值を 求めて把握時の筋の活動水準の指標 (IEMG) とした。

\section{3. 結果および考察}

$3 \cdot 1$ 短時間および静的把握時の最大保持力径 バケツに水を注ぐ静的条件下の円筒保持力は，ある特 定の径で最大值を示すことが知られている(1). 本実験 の被験者 2 名の円筒径 $(\mathrm{D})$ 亿伴亏保持力 $(\mathrm{F})$ の変化を 図 5 に示す。关の結果, 保持力の最大值は被験者 $\mathrm{MK}$ に扔いては $D=40 \mathrm{~mm}$, 被験者 $\mathrm{SM}$ に扔いては $D=$ $35 \mathrm{~mm}$ であった。これは, 前報(1)での $D=35 \sim 42$ $\mathrm{mm}$ とほほ一致した範囲に每る。上述の 2 名の被験 者 $\mathrm{MK}$ と SM の短時間把握時の保持力 $(\mathrm{F})$ の変化を 示したのが図 6 である。この場合にも，保持力はある 


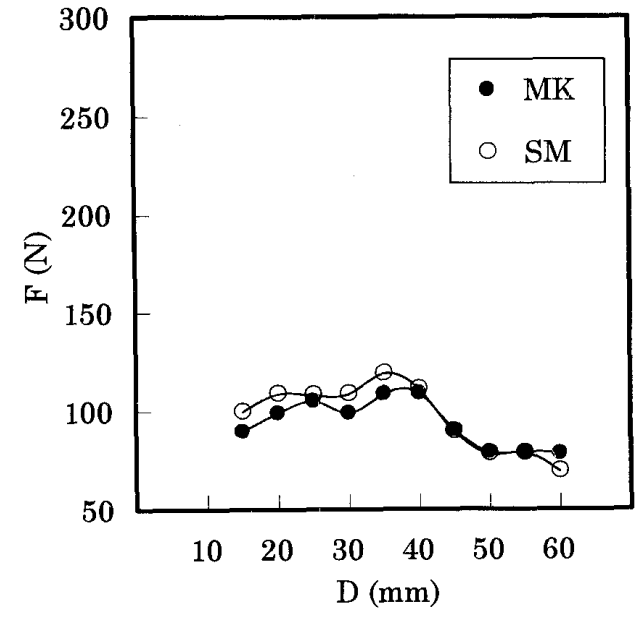

Fig. 5 Effect of grasping diameter $D$ on holding force $F$ under static loading

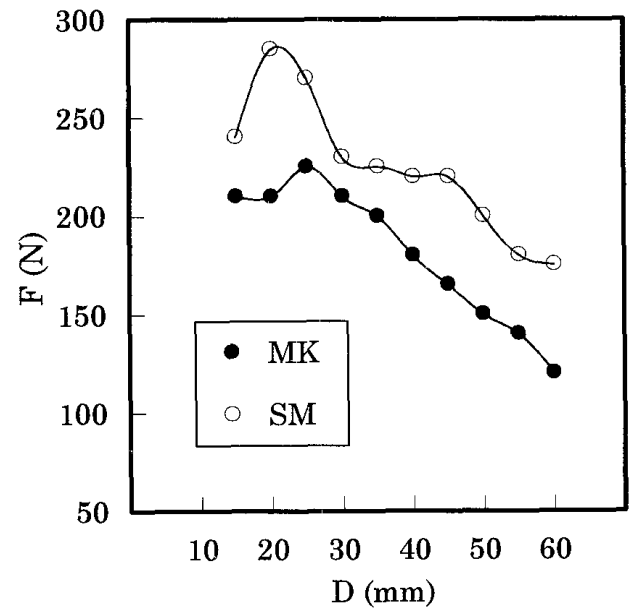

Fig. 6 Effect of grasping diameter $D$ of holding force $F$ under rapid loading

特定の径で最大值を示した。しかし，短時間把握での 保持力の最大值が発現する径をみると, 被験者 $\mathrm{MK}$

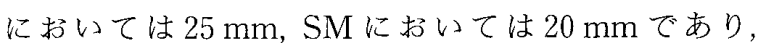
静的条件よりも $15 \mathrm{~mm}$ 細功た。被験者全員の最大 保持力径は 20 から $25 \mathrm{~mm}$ であった，次に，保持力を 両条件で比較すると, 保持力は, 静的条件では 75 125 N の範囲にあり最大值は $120 \sim 125 \mathrm{~N}$ に分布 した。それに対して, 短時間把握では $100 \sim 300 \mathrm{~N}$ の 範囲で 200〜300 N の間に最大值がみられた。すなわ ち, 短時間把握では静的把握より約 2 倍近い大きな力 が発揮でき，円筒径の違いが保持力に大きく影響して いる．同様な傾向はすべての被験者に共通していた。 この傾向については静的㧍よび短時間把握で結果は同 様である。また，図 5 と 6 の比較から，短時間負荷条 件では静的な場合よりも保持力の個人差が大きく現れ ることがわかる。

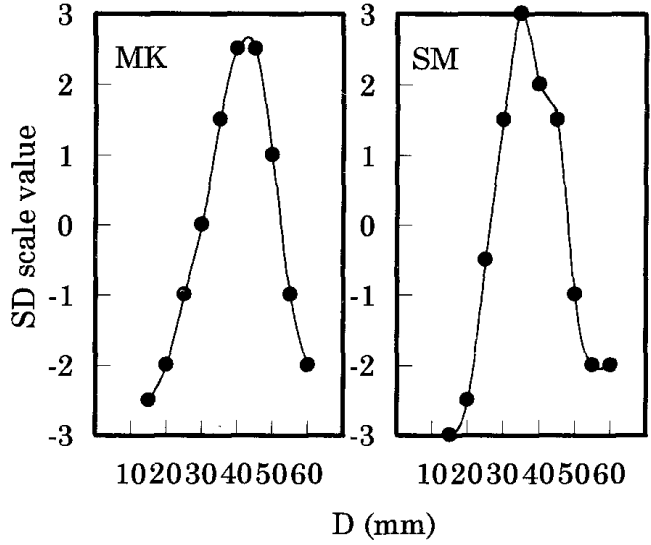

Fig. 7 Relationship between SD scale value and grasping diameter $D$ under static loading

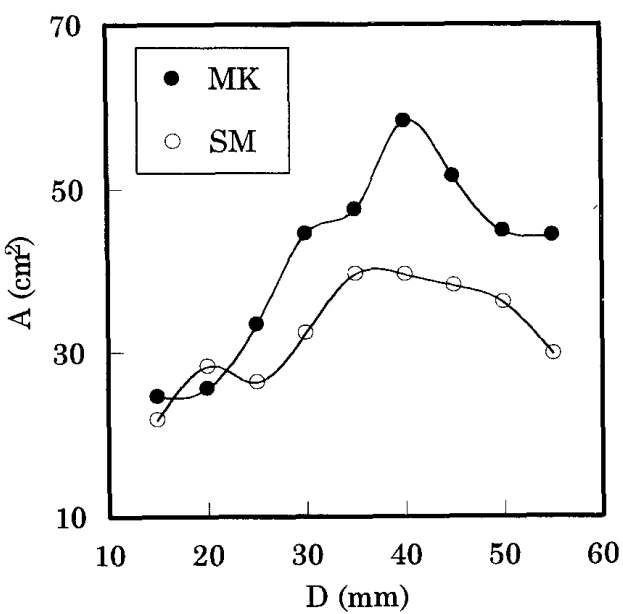

Fig. 8 Contact area between hand and cylindrical object $A$ and grasping diameter $D$ under static loading

以上のことから，発揮できる力は，短時間把握では， 静的把握に比べて大きく，把握する円筒径は，より細 い径で最大值を示すことが明らかとなった。

\section{$3 \cdot 2$ 短時間および静的把握における円筒保持力の} 差の原因 静的把握においては, 最大保持力と手一 物体間の接触面積の最大値が一致することが確認され ている(1). 図 5 执よび 6 におけるのと同一の被験者に 対する，握りやすさの感性評価(SD scale value)の結 果を図 7 亿, 手一円筒間の接触面積 $(\mathrm{A})$ の結果を図 8 に示した。ここで, 図 7 の繸軸は前報と同様な SD 法(2)によって求めた評価であり，一3(非常に握り難 い)から 3(非常に握りやすい)までの 7 段階で主観的 な握りやすさを示している。図には,太い径から順に 握り始めた場合と細い径から順に握り始めた場合の 2 回の計測の平均值を示してある.把握時の手と物体の 接触面積は，前報(1) と同様に円筒の表面に壘を塗り， 把握後, 墨のついた手の写真を撮り,求めた。その結果, 
図 7 および 8 に示すとおり最大值は被験者 MKにお いては $D=40 \mathrm{~mm}$, 被験者 $\mathrm{SM}$ においては $D=35$ $\mathrm{mm}$ でみられ, $3 \cdot 1$ 節で示した静的な条件での最大保 持力径と一致することが確認できる，接触面積は，手 の皮膚加の感覚入力の量に詨応していると考方ら れ，このことが，接触面積が最も大きくなる円筒径が， 最も握りやすい径および静的把握での最大保持力径と 一致することの要因の一つとなっていると考えられて いる(1).しかしながら，短時間把握では，最大保持力 径は被験者 MKにおいては $25 \mathrm{~mm}$, 被験者 SMにお いては $20 \mathrm{~mm}$ であり，最も握りやすい径や接触面積 が最大となる円筒径とは一致せず，それより細い。ま た，円筒との接触面積 $(\mathrm{A})$ と短時間把握における保持 力 (F)の間には依存性が認められない(図 9). したが って, 静的より短時間負荷条件で最大保持力径が細く なることは，短時間把握のほうが発揮する力に対する 皮膚からの感覚情報の寄与率が低いことに起因してい る可能がある。

静的把握に打ける最大保持力径は, 最も小さい力で 円筒を保持できる径と一致する(1).この場合では，保 持力を前腕部(図 3 参照)筋の収縮に伴う太さ変化から 計測している(1)。この方法は簡便で有効である反面, 把握に関与する手内筋(骨間筋や母指内転筋などの手 の平の筋, 図 3 参照) の発揮する力の評価が困難であ ること，分解能が十分高いとはいえないことなどの問 題点がある。そこで，手内筋を含め手の各筋の情報を 分けて取り出せ，しかも計測精度の高い表面筋電図を 用い，短時間把握の特性を調べた。図 10 に，被験者 MKに扔いて得られた結果を示す。結果は各径で得

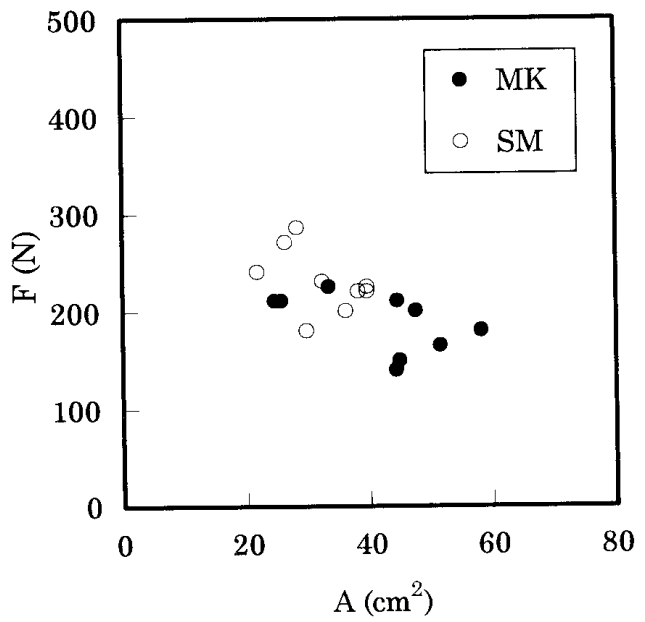

Fig. 9 Relationship between holding force under rapid loading $F$ and contact area between hand and cylindrical object under static loading
られた積分值を最大保持力径の積分值で規格化して表 している. また, 負荷は, 最大保持力の $10 \%$ とし，こ の力を約 0.5 秒で負荷し 10 秒間保持した. 負荷保持 直後から 5 秒間の筋電図について積分值を求めてい る.実験では，図 3 に示した 4 箇所から測定したが, 四つの筋とも最大力保持径の把握時に積分值が最小值 を示している．積分值の大きさは各筋ごとにかなり差 があるが,このことは, 一定の重さの円筒を把握した とき，最大の力が保持できる径で筋の活動水準が最も 低くなることを示している(3). 寸なわち，最大保持力 径を把握するときの筋の把握に対する筋の寄与率が最 も低いことを反映しているものといえる，特に，母指 内転筋 AP は, 最大保持力径より太い径においては径 の増大に伴い著しい増加を示しているが，最大保持力 径より細い径においてはその増加が小さく，最大保持 力径での值と大きな差が見られない。母指内転筋 $\mathrm{AP}$ は，母指の内転に作用する筋であるが，静的把握にお いては円筒径が細いと母指以外の 4 指を中心とした把 握形態をとることによると考えられる(1).この傾向は 今回の被験者に扔いても認められた。把握する円筒径 によって把握に関わる各指ごとの度合が変化すること が, 筋電図積分値の変化の差異として現れていると考 えられる。

以上の結果から，把握にかかわる各筋の寄与が異な るものの, 短時間把握においても, 最大保持力径は発 揮筋力が最も小さい円筒径と一致することが確かめら

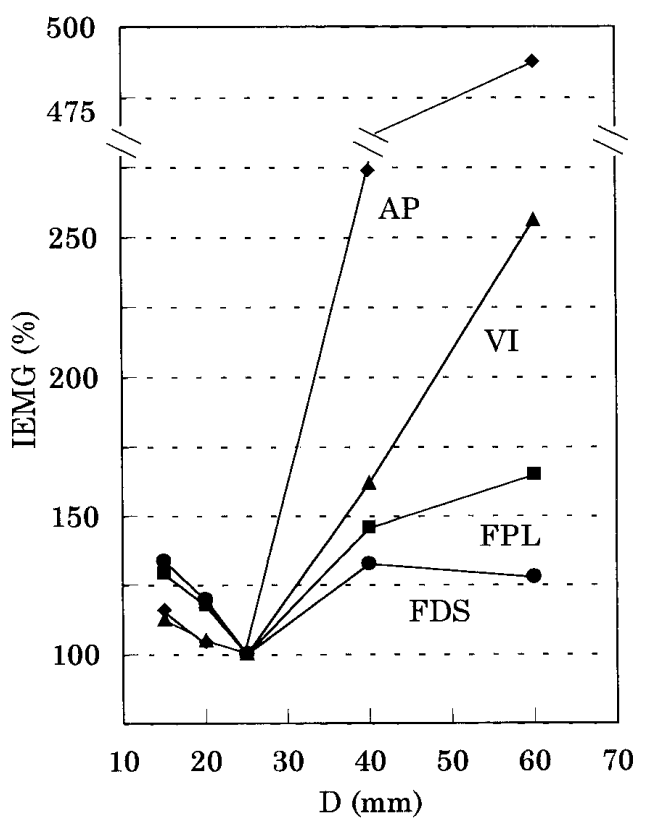

Fig. 10 Changes in integrated value of electromyographic signals (IEMG) against diameter of cylindlical object under rapid loading 


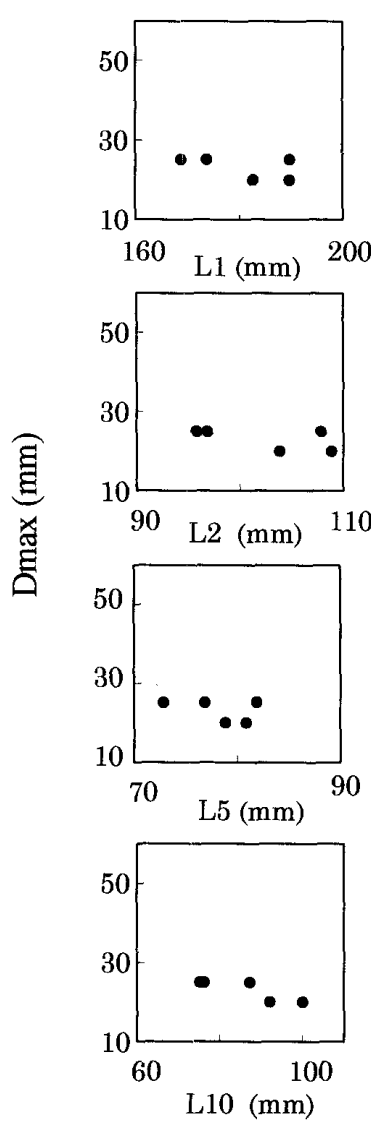

Fig. 11 Relationship between diameter of holding force and dimensions of hand under rapid loading

れた。したがって，前報(1)の結果と合せて考えると静 的把握拉よび短時間把握のいずれの場合にも，最も効 率よく指の筋活動を行うことができる把握が, 最も大 きな力を発揮できる把握となることが明らかとなっ た。

\section{$3 \cdot 3$ 短時間把握での最大力保持径の個人差につい}

$\tau$ 最大保持力径は, 手と円筒の接触面積に関係す ることから手の大きさに依存している可能性がある。 本実験の被験者の手の大きさは, 表 1 に示すように, 各パラメータに扔いて最も大きい者と小さい者の間に 9 から $25 \mathrm{~mm}$ という大きな差があった。 5 人全員の 最大保持力径と手の大きさのパラメータとの関係を図 11 亿示す. 被験者全員の手の大きさの各種パラメー 夕と最大保持力径 $\left(D_{\max }\right)$ の間に明らかな関係は見ら
れなかった．最大保持力径が手の大きさに依存しない ことは，最大保持力径の決定には，手の大きさといっ た解剖学的な因子上り, 各個人の過去の履歴に由来す る把握動作様式の差異あるいは動作様式が同様であっ ても神経系の適応の差異といった因子が強くかかわっ ている可能性がある. しかし，手の大きさにかかわら ず被験者全員の最大保持力径が 20 から $25 \mathrm{~mm}$ であ ったことから，短時間に大きな力を発揮する場合に使 用する道具の径は，個人差を考元ずに画一的な径であ ってもよい可能性がある。そその反面, 図6亿示すよう に径が $5 \mathrm{~mm}$ 異なるだけで, 保持力が約 $40 \mathrm{~N}$ 低下す る場合があることから考えると，画一的とは逆に精密 に個人に適合した握り径を設定する必要があるであろ う.

\section{4. 結語}

円筒物体把握における径と保持力の関係を明らかに することを目的として, 5 秒以内の短い時間内に最大 値に達するような短時間負荷条件の下における保持力 について調べた。

（1）短時間把握での最大保持力径㹥手の大きさに よらず 20〜25 mm の範囲にあり，保持力は 100〜300 $\mathrm{N}$ に達した。これらは，静的把握と比較すると，保持 力注約 2 倍大きく, 最大保持力径は約半分の太さであ った.

（2）一定負荷の下での把握時の手の筋から導出し た筋電図の積分値は, 最大保持力径において最も小さ く, 最大保持力径では, 筋力が効率上く円筒物体に伝 達されているものと思われた.

（3）最大保持力径は手一円筒間の接触面積および 握りやすさと関係しなかった.

\section{文献}

（1）八高隆雄・荒川進・高田一，手-円筒物体間の力伝達，機 論, 60-573, C (1994), 1721-1726.

（2）八高隆雄・山本圭治郎・小山昌洋・兵頭和人，円筒物体 把握に打ける握り易さの感性評価，機論， 62-602, C (1996), 3999-4004.

（3）小林茂夫, 表面筋電図の測定, 処理, 分析, Jpn. J. Sports Science., 2(1983), 671-685. 